concern, and if a profit is to be made, it should not have to carry expenditure incurred for work undertaken to beautify a locality; an object quite apart from the utilisation of the soil as a commercial asset. Mr. Dallimore dealt with the various types of planting for amenity purposes, such as garden and park trees, field and hedgerow trees, road-side trees, small shelter plantations and woods of varying type open to the public as pleasure resorts.

\section{Weather in Great Britain and Ireland in 1933}

THE most recently published annual volume of the Weekly Weather Report (The Weekly Weather Report for the Period February 26, 1933 to March 3, 1934. M.O. 374. London: H.M. Stationery Office. $7 s .6 d$., postage extra) is the fifty-sixth that has appeared since the publication of meteorological data in weeks by the Meteorological Office was first begun, and is the fifth in which the data are largely presented in the form of deviations from normal values of the different elements. The deviations of temperature are given in whole degrees, of accumulated temperature (reckoned from $42^{\circ} \mathrm{F}$., the zero of temperature from the point of view of plant growth) in day degrees, while for rainfall and sunshine the percentage of the normal for the appropriate week or season is quoted. This report is designed to be used for correlation with agricultural data, for which as a time unit the day is regarded as being too short, and the month too long. The year begins and ends, as in former volumes, with early spring, the whole period under review in this case beginning on February 26, 1933, and ending on March 3, 1934, and the tables are based on the records of fiftyseven stations well distributed throughout Great Britain and Ireland. The time of commencement was for England within a wet period following a remarkably dry winter, which came at a favourable time for agriculture in so far as it supplied the land with some reserves of water, and enabled many crops to withstand the drought, heat and abnormal sunshine of the summer and autumn of 1933 far better than they would have done had the winter drought not had this pronounced check. The period as a whole was with few exceptions one with excess of sunshine over England, especially in the south-east and the Midlands. There was general dryness and warmth throughout the British Isles, the warmth being especially pronounced in spring and summer; July and August provided more than one spell of tropical heat, without however quite repeating the very exceptional extremes of the August of the preceding year.

\section{Recent Acquisitions at the Natural History Museum}

Among the recent acquisitions of the Department of Zoology is a collection of 300 birds obtained by Mr. A. W. Vincent in the south-eastern district of the Belgian Congo. This is an area which has been very little investigated from the ornithological point of view. A valuable recent addition to the collection of Hemiptera (bugs) in the Department of Entomology consists of a collection of 17 specimens of
Termitaphidæ presented by Dr. J. G. Myers of the Imperial College of Tropical Agriculture, Trinidad. These rare and little-known insects are found only in the nests of white ants in America and in the Old World, but the nature of this association is not known. A purchase of particular interest is a collection of 500 beetles from Tibet, Central Asia, western China and the Altai Mountains ; the majority of the specimens were described by Continental authors and are paratypes of species hitherto unrepresented in the Department. The Public Schools Exploration Society has presented the whole of the entomological collections made during its recent expedition in Newfoundland. The Department of Geology has acquired a collection of primitive fish-like Ostracoderms comprising a hundred specimens obtained by Mr. Wickham King, chiefly from the Old Red Sandstone of Worcestershire; and a fine series collected by Dr. E. I. White and Mr. H. A. Toombs from Herefordshire, comprising many forms new to science, of which the most interesting are specimens of Pteraspis, which show for the first time the unusual form of the tail. A valuable collection of gemstones has been bequeathed to the Department of Minerals by the late Mr. T. B. Clarke-Thornhill, including ninety cut stones, many of them of large size, of various minerals-a fine series of sixteen coloured diamonds, parti-coloured corundum, tourmaline, opal, alexandrite, phenakite, etc.; also uncut specimens of opal, moonstone, and large masses of Kauri-gum from New Zealand. The first meteorite to be recorded from Rhodesia, a stone weighing $48 \mathrm{lb} .11 \mathrm{oz}$. which fell on March 7, 1934, in the Mangwendi native reserve, $\mathbf{4 0}$ miles east of Salisbury, has been presented by the Government of Southern Rhodesia.

\section{Proposed Museum at Verulamium}

The City Council of St. Albans is preparing plans and proposes to seek powers for raising $£ 15,000$ for the erection of a museum on the site of the RomanoBritish city of Verulamium. The museum will be devoted to housing the valuable collection of antiquities found on the site during its recent excavation by Dr. and Mrs. Mortimer Wheeler. The proposal of the Council is a fitting sequel to its enlightened action whereby the excavation, which has proved so fruitful in results, was made possible. Not only has the importance of Verulamium as a centre of RomanoBritish life and culture been fully confirmed by increased knowledge, but also it is now possible to appreciate more justly the significance and influence of this centre in relation to the rest of the peoples of pre-Roman Britain. The value of the collections to the student will be vastly enhanced by the opportunity the building will afford for the proper display of these antiquities without the distraction of other exhibits by their side; while the effect of such a display as a unitary collection in the midst of its native setting will be to enhance both its historical and its cultural value. The Council is wisely consulting Dr. Mortimer Wheeler before deciding on the exact site of the museum in order to avoid the possibility of interference with any future exploration. 